\title{
A quantitative evaluation of color changes occurring in the muscle tissue during the stages of S10 silicone plastination technique
}

\author{
Burcu INSAL ${ }^{1, \mathrm{a}, \varpi}$, R. Merih HAZIROĞLU ${ }^{1, \mathrm{~b}}$ \\ ${ }^{1}$ Ankara University, Faculty of Veterinary Medicine, Department of Anatomy, Ankara, Turkey \\ aORCID: 0000-0003-3354-6424; ' ORCID: 0000-0001-9049-4136 \\ Corresponding author: burcuinsal@gmail.com \\ Received date: 10.06.2020 - Accepted date: 24.11.2020
}

\begin{abstract}
There are many preservation techniques that are used to ensure that the changes (odor, color, and elasticity) in the characteristics of the animal or human bodies after death are minimized in the field of anatomy. One of the most modern anatomic specimen preparation methods is the plastination technique. Therefore, primary plastination stages were applied to the muscle tissue in this study. The aim of the current study is to present color changes in muscle tissue quantitatively by using a colorimeter device in every stage of the standard silicone plastination technique until the last product is obtained. Color analyses were performed on the muscle tissue after each stage of the plastination. Throughout the whole process, it was observed that the stage when the value of color change from green to red in the product was the closest to the fresh tissue was the $1^{\text {st }}$ acetone bath. The value of color change from blue to yellow was closest to the fresh tissue at the gas curing and hardening stage. Furthermore, the closest values to the fresh tissue were recorded after the impregnation stage when the variations in plastinates were evaluated in terms of brightness. Color changes in plastinates, which have been described as close to the natural color up to today, were determined through statistical data in this study. Moreover, as a result of this dissertation, it was asserted that colorimeter can be effectively used in the field of anatomy due to the advantages it holds.
\end{abstract}

Keywords: Colorimeter, plastination, S10.

\section{S10 silikon plastinasyon tekniği aşamalarında kas dokusunda meydana gelen renk değişimlerinin kantitatif olarak değerlendirilmesi}

Özet: Anatomi biliminde, ölümden sonra hayvan veya insan bedenlerinde meydana gelen değişikliklerin (koku, renk, elastikiyet) en aza indirilmesini sağlamak için kullanılan birçok koruma tekniği vardır. Bu teknikler arasında, bilinen en modern anatomik örnek hazırlama yöntemlerinden biri, plastinasyon tekniğidir. Bu sebeple bu çalışmada kas dokusuna temel plastinasyon aşamaları uygulandı. Çalışmada, standart silikon plastinasyon tekniğinde son ürün elde edilene kadar geçen her aşamada kas dokusunda meydana gelen renk değişimlerinin kolorimetre cihazıyla sayısal olarak ortaya konulması amaçlandı. Plastinasyonun her aşamasında, kas dokusuna renk analizi yapıldı. İlk aşamadan son aşamaya kadar olan tüm süreç boyunca renk değişimi değerlendirildiğinde; elde edilen son üründeki yeşilden kırmızıya renk değişiminin taze dokuya en yakın olduğu aşamanın; 1. aseton banyosu olduğu gözlemlendi. Maviden sarıya değişimin taze dokuya en yakın olduğu aşamanın ise gaz kürleme ve sertleştirme aşaması olduğu görüldü. Ayrıca plastinatların parlaklık açısından değişimi ele alındığında; taze dokuya en yakın değerleri, vakumla gömme aşamasından sonra kaydedildi. Yapılan bu çalışmayla, bugüne kadar doğal renge yakın olarak tanımlanan plastinatlardaki renk değişimi sayısal verilerle belirlendi. Bununla birlikte bu tez çalışması sonucunda kolorimetre cihazının, sahip olduğu avantajlar sebebiyle, anatomi alanında oldukça etkili bir şekilde kullanılabilir olduğu ortaya konuldu.

Anahtar sözcükler: Kolorimetri, plastinasyon, S10.

\section{Introduction}

Preservation of cadavers without disintegration as much as possible is of great importance in the field of anatomy $(1,2,15,22)$. Techniques used to preserve human or animal bodies after death for the purpose of using them as training and research material and exhibiting them in museums date back to ancient times (1, $2,8,22)$. No matter how good preservation it is in, a number of changes occur in the flexibility, color, and tissue integrity of cadavers in classical anatomic methods (4). When the last products obtained as a result of plastination (plastinates) are compared to the specimen 
prepared with conventional anatomical techniques, they are not only durable but also preservable for many years $(3,19)$.

Plastination is a process used to remove water and fat in tissues through chemical dehydrators (acetone, alcohol, etc.) with the help of various chemicals and physical factors. Then, the dehydrators replace them with a chemically active polymer (silicone, epoxy, polypropylene, orthocryl and polyester copolymers) and stabilize them in the tissue $(3,5,19,24,27)$. Silicone plastination is the most common technique among all plastination techniques. Silicone plastination consists of 5 consecutive stages that are based on chemical and physical laws. These stages are specimen preparation, dehydration, defatting, forced impregnation, and gas curing-hardening (3).

As a result of these processes, plastinates which have visual (transparent/matte) and mechanical (flexible/rigid) characteristics, varying depending on the polymer type used, are obtained as end products which are odorless, durable, preservable for many years and harmless to human health $(18,19)$. However, one of the most major problems of the plastination technique is its inability to fully preserve the natural color of biological tissues and organs $(13,23)$. Color is the most important determiner of a product's quality in many fields $(7,10,28)$. Colors can be measured through different methods of measurement and can be converted into quantitative data. $(12,14,28)$. Colorimetry is defined as a color measurement method which was developed in order to present colors quantitatively and exhibit color differences among specimens. These devices display the brightness ratio as $\mathrm{L}^{*}$ (between values of 0 - 100), degree of color change (between the values of $-120-120$ ) from green to red as $a^{*}$ and from blue to yellow as $b^{*}$ on the coordinates and quantitative values in $\mathrm{L}^{*} \mathrm{a} * \mathrm{~b} *$ standards determined by CIE (International Commission on Illumination) $(10,16$, 26, 28).

In the studies conducted so far, there has not been enough literature showing that the plastinates are measured by any color analysis system stage by stage. For that reason, the aim of the current study is to quantitatively present various color changes that might occur in any stage of the plastination.

\section{Material and Methods}

In this study, muscle tissue belonging to an adult sheep (Ovis aries) was obtained from a licensed slaughterhouse (Ethical Committee Number: 2017-3-18). M. longissimus cervicis, thoracis and lumborum sections were used. First, a detailed procedure of dissection was conducted on $\mathrm{m}$. longissimus in order to remove the surrounding adipose and connective tissue. Following this procedure, total of 10 specimens were prepared in a way that $2 \mathrm{~cm}$ wide incised sections were removed from the tissue. Each section was marked on 3 points. Initial color analyses were conducted on the marked sections of fresh muscle tissue in the first hour following the slaughter (7, 26) in order to set reference color values. After that, specimens were fixated in a $10 \%$ formalin solution at room temperature within a time frame of 24 hours. At the end of this period, second color measurements were performed from the marked points.

Upon the procedure, specimens were kept under running water for 2 days to remove the formaldehyde residue. As the next step, specimens were taken into a pure (99.5\%) acetone bath at $-25^{\circ} \mathrm{C}$. The acetone to tissues ratio was set as 10:1. After acetone concentration was fixated at a certain value, color changes in specimens were remeasured. After that, specimens were taken to the second acetone bath and were measured each day. Since the acetone was fixated at a value of $>99 \%$, specimens were subjected to colorimetric measurement again without requiring a $3^{\text {rd }}$ bath. The defatting process (27) that is a stage applied for tissues and organs with dense adipose tissue, was not applied because the muscle tissue did not contain dense adipose tissue. Then the samples were taken to the impregnation stage. At this stage, acetone that was replacing the tissue fluids was evaporated under negative pressure and removed from the tissue and so replaced with the silicone polymer. While preparing the silicone polymer, a mixture at a ratio of 1:100 was formed from 2 important chemical agents used in this stage: Biodur ${ }^{\circledR}$ S10 silicone polymer and its catalyzer Biodur ${ }^{\circledR}$ S3 chemical agent. The outflow of gas bubbles was adjusted with a valve connected to the vacuum tank in a $5 \mathrm{~cm}^{2}$ area in a way that it output 1-3 bubbles per second. The outflow of bubbles was observed for 6 days. Since there was no observable bubble outflow when Bennert manometer displayed $<5 \mathrm{~mm}-\mathrm{Hg}(21)$ and the valve was completely shut, impregnation stage was considered as completed. Specimens were left to rest hanging in the silicone tank for 24 hours after being taken out from the mixture of S10/S3 in order for the extra silicone to be filtered from the tissue. Then, specimens were taken into a resting period for 2 more days at room temperature so that the extension of the chemical chain reaction could continue. The main purpose here was to acquire specimens that are more durable. Specimens were subjected to color analysis once more. After that, specimens were placed in the tank of gas curing and hardening. Hardening agent Biodur ${ }^{\circledR}$ S6 in a glass container was placed into the curing tank which was isolated from the external environment. $400 \mathrm{l} / \mathrm{hr}$ airflow was given to the curing tank through an air engine externally integrated to the curing tank for an hour two times a day, in order for S6 to evaporate slowly and turn into the gas state and for cross-reactivity to start. Deep surfaces of the specimens that started hardening on the 
surfaces were subjected to gas curing and hardening for 10 days in order for the cross-reactivity to start. At the end of this period, specimens were removed and last color analyses were performed to be compared with previous measurements. The data from the color measurements were evaluated with the SPSS 14.01 package software used in the analysis of variance for repeated measures. Whether the data was normally distributed was checked through the Shapiro Wilk test. For all statistical evaluation, $\mathrm{P}<0.05$ was used as the criterion.

\section{Results}

For color analysis, the values taken from fresh tissue were first compared with the measurements made after the fixation step. It was observed that value $\mathrm{dE}^{*}$, an indicator of a visible degree of color change, was considerably high as shown in Table $1(\mathrm{P}<0.001)$. Specimens that were taken to a pure acetone bath were dehydrated at $96.5 \%$ acetone concentration at the end of the $4^{\text {th }}$ day. Before the $2^{\text {nd }}$ acetone bath, the degree of color change in the specimens was recorded as shown in Table 1. The acetone concentration was fixated at $99.2 \%$ on the $3^{\text {rd }}$ day of the second acetone bath. Thus, the $2^{\text {nd }}$ acetone bath was completed at the end of the $6^{\text {th }}$ day. Color analyses were performed again (Table 1). Specimens taken to the resting period following the impregnation were subjected to the measurement again at the end of this chemical process. When the results were compared, it was observed that the $L^{*}$ value was highest in the fixation stage. The difference between $\mathrm{L}^{*}$ value recorded after the stage of impregnation and the $\mathrm{L}^{*}$ value taken from a fresh tissue was recorded as the closest values of $\mathrm{L}^{*}$ with 13.74 units of value. In addition, $\mathrm{a}^{*}$, which is the mean degree of color changes from green to red on fresh tissue, was close to the color red. However, it was observed that while this value was recorded as having moved away from red with 6.6 unit of value on average after fixation. Nevertheless, value $\mathrm{a}^{*}$ moved towards the color red again with 5.87 units of value on average after the stage of impregnation. Furthermore, whereas $b^{*}$, the degree of color change from yellow to blue on the fresh tissue, was close to yellow with 3.74 unit at the beginning of the study. It was recorded that the $b^{*}$ value increased by 6.17 unit after fixation. Additionally, value $b^{*}$ continued to increase by 2.08 units of value in favor of yellow after the impregnation. These changes were shown on the wavelength scatterplot in Figure 1. At the end of 10 days when the impregnation processes were completed, specimens that were moved into the stage of gas curing and hardening were taken to color analysis for the last time. Recent values have been shown in Table 1 and Figure 1. When the color values of the end products were compared with the fresh tissue, it was observed that tissues lost their red color value, $a^{*}$, by 6,33 units of value. The ratio of tissue brightness, $L^{*}$, increased by 19.52 units of value. On the other hand, the specimens moved towards yellow color, $b^{*}$, by 6.01 units of value $(\mathrm{P}<0.001)$. After all stages, the specimen's observable color change value, $\mathrm{dE}$; changed by 21.04 units of value (Figure 1). During the whole process, it was observed that the last product was closest to the fresh tissue after the $1^{\text {st }}$ acetone bath in terms

Table 1. Color and brightness measurements of muscle tissue at all stages of plastination.

\begin{tabular}{|c|c|c|c|c|c|c|c|}
\hline \multirow[b]{3}{*}{ Parameters } & \multicolumn{4}{|c|}{ S10 Silicone Plastination Steps } & \multirow[b]{3}{*}{ İmpregnation } & \multirow{3}{*}{$\begin{array}{c}\text { Gas Curing- } \\
\text { Hardening }\end{array}$} & \multirow[b]{3}{*}{$\mathbf{P}$} \\
\hline & \multirow[b]{2}{*}{ Fresh Tissue } & \multirow[b]{2}{*}{ Fixation } & \multicolumn{2}{|c|}{ Dehydration } & & & \\
\hline & & & $\begin{array}{l}1^{\text {st }} \text { Acetone } \\
\text { Bath }\end{array}$ & $\begin{array}{l}2^{\text {nd }} \text { Acetone } \\
\text { Bath }\end{array}$ & & & \\
\hline $\mathrm{L}^{*}$ & $32.6 \pm 1.02^{d}$ & $54.02 \pm 0.46^{\mathrm{a}}$ & $52.74 \pm 0.42^{b}$ & $52.62 \pm 0.49^{b}$ & $46.34 \pm 0.32^{c}$ & $51.58 \pm 0.31^{b}$ & \\
\hline$a^{*}$ & $13.09 \pm 0.26^{\mathrm{ab}}$ & $6.49 \pm 0.16^{\mathrm{c}}$ & $13.32 \pm 0.44^{\mathrm{a}}$ & $12.45 \pm 0.39^{b}$ & $12.36 \pm 0.34^{b}$ & $6.76 \pm 0.23^{c}$ & \\
\hline$b^{*}$ & $3.74 \pm 0.33^{c}$ & $9.91 \pm 0.22^{b}$ & $11.95 \pm 0.19^{a}$ & $11.89 \pm 0.21^{\mathrm{a}}$ & $11.99 \pm 0.22^{a}$ & $9.75 \pm 0.31^{b}$ & $<0.001$ \\
\hline $\mathrm{dE}^{*}$ & - & $23.34 \pm 0.62^{\mathrm{a}}$ & $21.85 \pm 0.83^{b}$ & $21.73 \pm 0.69^{b}$ & $16.18 \pm 0.83^{c}$ & $21.04 \pm 0.82^{b}$ & \\
\hline
\end{tabular}

a,b,c Values within a row with different superscripts differ significantly at $\mathrm{P}<0.05$ and $\mathrm{N}=10$.

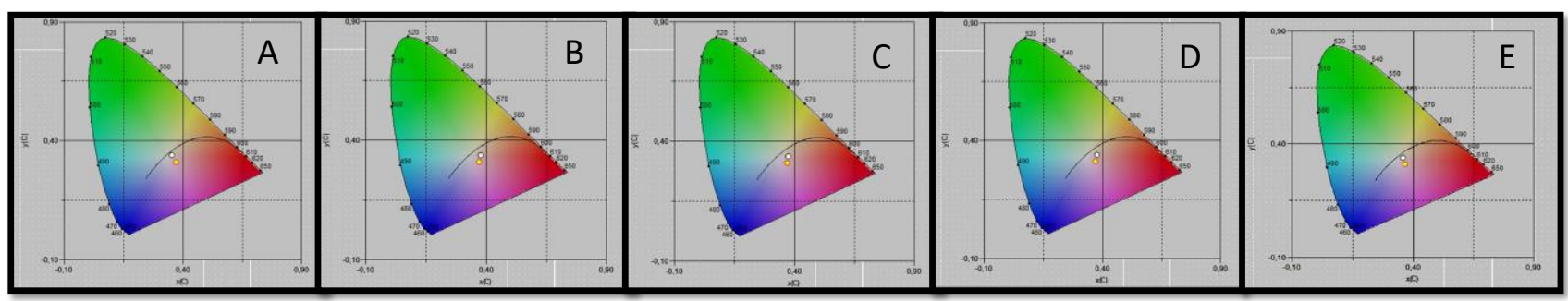

Figure 1. The wavelength distribution graph of the color change at all stages of plastination on the X-Y plane. A: fresh tissue, B: fixation, C: dehydration, D: impregnation, E: gas curing-hardening. 
of $\mathrm{a}^{*}$ values. In addition, it was observed that the last product was closest to the fresh tissue after the stage of gas curing and hardening in terms of $b^{*}$ value. Moreover, when the variation in plastinates' brightness was examined, the closest values to the fresh tissue were recorded after the stage of impregnation (Figure 1).

\section{Discussion and Conclusion}

In many articles, plastinates, obtained through plastination technique, are defined as "odorless, lasting products, harmless to human health and 'identical to natural color", $(11,15,18-20)$. However, in response to the statement of identicalness to the natural color, certain researchers $(6,13,17)$ stated that some stages of plastination lead to loss of color in plastinates. Therefore, the possible color losses in each stage of the standard silicone technique were observed in this study. Huidobro et al. (7) reported that meat quality and accordingly the color can change depending on the age, race and raising methods in the study they carried out in 2003. For that reason, the material was taken from a single sheep and it consisted of 10 specimens. Turan et al. (25) took specimens from fresh muscle tissue (m. quadriceps femoris) from the goats on the $24^{\text {th }}$ hour and subjected it to color analyses. According to Turan et al. (25), the values obtained from the fresh muscle tissue are $\mathrm{L}^{*} ; 20.86$ $\pm 1.74, \mathrm{a}^{*} ; 1.22 \pm 0.57, \mathrm{~b}^{*} ; 2.26 \pm 0.95$. On the contrary, Karabacak et al. (9), calculated the color of fresh muscle tissue (m. longissimus) taken from Malya lambs on the 24th hour as L*; $39.53 \pm 0.511, \mathrm{a}^{*} ; 15.46 \pm 0.322 ; \mathrm{b}^{*} ; 2.22$ \pm 0.421 . In this dissertation, results of color analysis of fresh muscle tissue ( $\mathrm{m}$. longissimus) belonging to an adult sheep on the $1^{\text {st }}$ hour following death were recorded as $\mathrm{L}^{*}$; $32.6 \pm 1.02, a^{*} ; 13.09 \pm 0.26, b^{*} ; 3.74 \pm 0.33$. These results show a significant difference when compared to the results of the study conducted by Turan et al. (25). However, they are strikingly similar to the results of the study of Karabacak et al. (9). According to these data, it was observed that analyses of muscle tissues belonging to the different parts of the body of different species of animals produced dissimilar results. Some studies $(2,25)$ report that fixation solutions and techniques can cause color changes on the cadaver. According to these studies, tissues lose their color in fixation solutions in which formaldehyde and different densities of formaldehyde are used due to the fact that formaldehyde rapidly coagulates the blood. In this case, tonal variation of the color gray is encountered on the tissues. According to the results of the current study, it was recorded that there was a value of 21.42 brightness on fresh tissues after fixation with a change in the value $\mathrm{L}^{*}$. Furthermore, tissues lost their red color $\left(a^{*}\right)$ by 6.6 unit of value whereas they increased their yellow color $\left(b^{*}\right)$ by 6.17 unit of value $(\mathrm{P}<0.001)$. These values confirm that fixation in plastination causes tissues to lose their color as asserted by some researchers $(6,13$, 17). When the color changes during the dehydration stage were compared the color changes after fixation, a 1.49 unit of value decrease was observed in $\mathrm{dE}^{*}$ value, which is the observable color change in tissues, after the $1^{\text {st }}$ acetone bath. Additionally, it was seen that $\mathrm{dE}^{*}$ value decreased by 1.61 unit of value in total at this stage as a result of a 0.12 unit of value decrease after the $2^{\text {nd }}$ acetone bath. This data indicates that after the removal of formaldehyde, in which acetone replaced the tissue fluids, brought the tissue close to its natural color to a certain extent $(\mathrm{P}<0.001)$. McCreary et al. (13) reported that color changes could occur in tissues (muscle, skin and connective tissue etc.) in fixation and dehydration stages. On the contrary, loss of color because of fixation decreased to a certain extent and it got closer to the values in the fresh tissue according to the color analysis performed after the dehydration stage. As the researchers indicated, whether this stage causes loss of color can be studied in specimens that plastination will be applied to without any fixation on their tissues. With the present study, color changes occurring on the last product, plastinates, which were acquired as a result of standard silicone plastination technique stage by stage were presented statistically.

Brightness ratio in tissues as $\mathrm{L}^{*}$, the degree of color changes from green to red as $\mathrm{a}^{*}$ and from blue to yellow as $b^{*}$ were shown on $\mathrm{X}-\mathrm{Y}$ coordinates with the colorimeter device used in the study and converted to statistical data in the value range determined in $\mathrm{L}^{*} \mathrm{a} * \mathrm{~b} *$ standards by CIE. The fact that these data were easily comparable among themselves was revealed in the study. It was proved that colorimetric method can be utilized as an anatomical specimen preparation technique as well as in evaluating the color quality of the end products. Color changes in each stage of plastination technique was analyzed individually and statistical data were compared among each other. Data obtained in the study were interpreted as significant results. Thereby, it was statistically presented that plastinates which are used as training material especially in the field of anatomy are anatomic specimens, similar to the natural color of tissues.

For that reason, it is considered that the data of this study will contribute to the science and training. It will be useful to conduct similar studies in different tissues and organs belonging to mammals and animal species other than mammals as well in terms of using and developing colorimetric analyses in anatomy. That colorimetric measurements can produce results on plastinates suggests the necessity of using this method in different anatomical preparation techniques. 


\section{Acknowledgements}

This article was developed from the thesis study prepared by Burcu Insal in 2017 (YOKSIS thesis number: 473688).

\section{Finacial support}

This research received no grant from any funding agency/sector.

\section{Ethical Statement}

This study was approved by the Ankara University Animal Experiments Local Ethics Committee (2017-318).

\section{Conflict of Interest}

The authors declared that there is no conflict of interest.

\section{References}

1. Ajayi IE, Shawulu JC, Ghaji A et al (2011): Use of formalin and modified gravity-feed embalming technique in veterinary anatomy dissection and practicals. J Vet Med Anim Health, 3, 79-81.

2. Brenner E (2014): Human body preservation-old and new techniques. J Anat, 224, 316-344.

3. Dejong K, Henry RW (2007): Silicone plastination of biological tissue: Cold-temperature technique BiodurTM S10/S15 Technique and Products. J Int Soc Plastination, 22, 2-14.

4. Eisma R, Wilkinson T (2014): From "Silent Teachers"' to Models. PLOS Bio, 12, 1-5.

5. Ezhilarasan S, Jetanthi M, Muthuvel VK (2017): Polyester plastination of human cadaveric specimens. Indian J Clin Anatom, 4, 26-29.

6. Henry RW, Janick L, Henry C (1997): Specimen preparation for silicone plastination. J Int Soc Plastination, 12, 13-17.

7. Huidobro FR, Miguel E, Onega E, et al (2003): Changes in meat quality characteristics of bovine meat during the first 6 days post mortem. Meat Sci, 65, 1439-1446.

8. Jangde S, Arya RS, Paikra S, et al (2015): How to provide a safe working condition for medical students and professionals in the anatomy dissection room. Sch J App Med Sci, 3, 1867-1870.

9. Karabacak A, Aytekin İ, Boztepe S (2012): Determination of fattening performance with some body measurements and carcass traits of Malya lambs at the open sheepfold. Arch Zootechnica, 15, 13-22.

10. Kays SJ (1998): Preharvest factors affecting appearance. Postharvest Biol Tec, 15, 233-247.

11. Kumar M, Kataria SK, Mantri LE, et al (2017): Study of plastination to preserve biological specimen in Western Rajasthan. Int J Appl Res, 3, 229-232.
12. Leo'n K, Mery D, Pedreschi F, et al (2006): Color measurement in $L^{*} a * b *$ units from RGB digital images. Food Res, 39, 1084-1091.

13. Mccreary J, Iliff S, Hermey D (2013): Silicone-based coloration technique developed to highlight plastinated specimens. J Int Soc Plastination, 25, 13-20.

14. Melendez-Martinez AJ, Isabel M. Vicario IM, et al (2005): Instrumental measurement of orange juice colour: a review. J Sci Food Agric, 85, 894-901.

15. O'neill GJ, Pais D, Andrade FF, et al (2013): Improvement of the embalming perfusion method: the innovation and the results by light and scanning electron microscopy. Acta Med Port, 26, 188-194.

16. Oliveria AC, Balaban MO (2006): Comparison of a colorimeter with a machine vision system in measuring color of Gulf of Mexico sturgeon fillets. Appl Eng Agric, 22, 583-587.

17. Oostrom K (1987): Fixation of tissue for plastination: general principles. J Int Soc Plastination, 1, 3-11.

18. Pandit S, Kumar S, Mishra BK (2015): Comparative study of anatomical specimens using plastination by araldite HY103, polypropylene resin, $6170 H 19$ Orthocryl and silicone-a qualitative study. Med J Armed Forces India, 71, 246-253.

19. Pashaei S (2010): A brief review on the history, methods and applications of plastination. Int J Morphol, 28, 10751079.

20. Ravi SB, Bhat VM (2011): Plastination: A novel, innovative teaching adjunct in oral pathology. J Oral Maxillofac Pathol, 15, 133-137.

21. Riederer BM (2014): Plastination and its importance in teaching anatomy. Critical points for long-term preservation of human tissue. J Anat, 224, 309-315.

22. Saeed M, Phil M, Rufai AA, et al (2001): Mummification to plastination. Saudi Med J, 22, 956-959.

23. Steinke H, Spanel-Borowski K (2005): Coloured plastinates. Ann Anat, 188, 177-182.

24. Stoyanov J, Georgieva A, Sivrev D (2015): Use of physical and chemical factors in the development of plastination anatomical preparations. Trakia J Sci, 13, 2122.

25. Turan E, Gules O, Kilimci FS, et al (2017): The mixture of liquid foam soap, ethanol and citric acid as a new fixative-preservative solution in veterinary anatomy. Ann Anat, 209, 11-17.

26. Vanezis P, Trujillo O (1996): Evaluation of hypostasis using a calorimeter measuring system and its application to assessment of the post-mortem interval (time of death). Forensic Sci Int, 78, 19-21.

27. Von Hagens G, Tiedemann K, Kriz W (1987): The Current Potential of Plastination. Anat Embryol, 175, 411421.

28. Wu D, Sun DW (2013): Colour measurements by computer vision for food quality control-a review. Trends Food Sci Tech, 29, 5-20. 